\title{
Primary Cutaneous CD30-Positive T-Cell Lymphoproliferative Disorder
}

National Cancer Institute

\section{Source}

National Cancer Institute. Primary Cutaneous CD30-Positive T-Cell Lymphoproliferative

Disorder. NCl Thesaurus. Code C7195.

This entity represents a spectrum of lymphoproliferative disorders characterized by CD30 (Ki-1)-positive cutaneous T-cell infiltrates. The two ends of the spectrum include lymphomatoid papulosis (benign end) and primary cutaneous anaplastic large cell lymphoma (malignant end). Borderline lesions are also included in this spectrum. (WHO, 2001) 